\title{
マイクロ吸盤の集積による吸着性柔軟ロボットスキン
}

\author{
眞 鍋 諒 一* 鈴 森 康 一** 脇 元 修 一*
}

\section{Adhesive Soft Robot Skin with Integrated Micro Suction Cups}

\author{
Ryoichi Manabe*, Koichi Suzumori* and Shuichi Wakimoto*
}

\begin{abstract}
This research aims at the development of a new functional robot skin on which micro suction cups are integrated to realize two functions of skin: "adaptive adhesion to rough/curved surfaces" and "anisotropic adhesion". This skin will be applied to various robot mechanisms such as robot hands and soles of wall-climbing robot feet. This paper reports the design concept of this skin and shows its potential experimentally. The experimental results are promising, which shows high adhesion force even on rough surfaces and asymmetric adhesion properties.
\end{abstract}

Key Words: Soft Mechanism, Micro Machine

\section{1. 緒言}

危険な場所での点検，メンテナンス，清掃などを用途とする 壁登りロボットの実用化で重要な要素の一つに, 走行面への吸 着デバイスが挙げられる. 近年, 新しい吸着原理を用いた研究 が進められている $[1] \sim[3]$. そのなかでも特に, 小型, 軽量の口 ボットに対しては, ヤモリの足裏剛毛を模倣した微細構造 [2] [3] が, 多様な壁面へも吸着できる可能性がある.

一般的な壁登りロボットの代表的な吸着原理として, 磁気力 を用いたもの [4], ロボットハンドによる把持動作を利用したも の [5], 吸盤内の吸引力を利用したもの [6] [7] が挙げられる。こ のうち, 磁気力および把持力は, それぞれ, 強磁性壁面, およ び被把持形状を有する壁面に使用が限定される。これに対して, 吸盤を用いた吸着は, 適用可能な環境が比較的広範囲であり, 研 究事例も多い [6] [12]. しかしながら, 被吸着面の凸凹で湾曲 による空気漏れが生じ，十分な吸着力がでない場合がある。

この問題点に対して, 前述の微細構造 [2] は, ヤモリの足裏 微細構造を参考とし, $2[\mathrm{~nm}]$ 以下の微視的な接触面で生まれる ファンデルワールス [13] を吸着原理とするため, 形状適応性抒 よび荷重方向による比較的速い着脱の切り替えが可能である. しかし, ファンデルワールスカは一般に小さく, 質量の小さい 小型のロボットの吸着機構に適用が限られる。実際に自然界を 見てみても, 足裏の微細構造による吸着力を利用する動物は, 八エや甲虫など小さなものが多く, 最大でも質量が $100[\mathrm{~g}]$ 程度 のヤモリになる [14]. 筆者らは, もう少し大型のロボットにも

原 2011 年 12 月 9 日

*岡山大学

*Okayama University

口本論文は提案性で評価されました。
適用できうる吸着機構として, 吸盤に着目した。本研究でいう 吸盤とは，ポンプ等による吸引によるもの [6]〜 [10] ではなく， 壁に押し付けることによって生じる負圧域を利用したパッシブ な吸盤 [11] [12] である。この吸盤は大気圧環境で使う場合には, 原理上 $100[\mathrm{kPa}]$ までの吸着力を単位面積当たり出すことがで きる.

そこで, 筆者らは, このような吸盤の特徵を生かしつつ, 曲面 や凸凹面に対しても吸着性を持った柔軟なロボットスキンの実 現を目指し，マイクロ吸盤を集積する研究に取り組んだ. Fig. 1 に，本研究で提案する柔軟スキンの概念図を示す，まず，「形状 適応性」では, 吸盤をマイクロスケールでゴム表面に集積形成 することで, 壁面の形状に適応することが容易になる，段差や 曲面が原因で負圧を維持できない吸盤がいくつか発生したとし

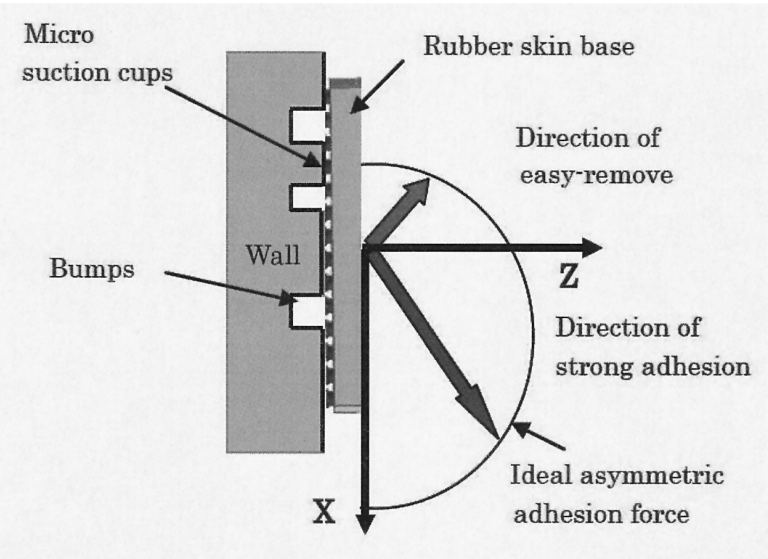

Fig. 1 Concept of functional adhesive soft robot skin with integrated micro asymmetric suction cups 
ても, 全吸盤の真空が一度に失われる可能性は低く, 全体とし て壁面への吸着力が維持できる。 また, 「非対称性」では, 形成 される各吸盤を非対称形状にすることで，引き離し方向によっ て吸着力の異なる特性を実現できる. Fig. 1 に示すように, あ る面に柔軟スキンが吸着している状態において, 吸着面に垂直 な方向に Z 軸を, それと直交する方向に X 軸をとり, 柔軟スキ ンに対して $\mathrm{X}-\mathrm{Z}$ 平面の任意の方向に力を加えて吸着面から引 き剥がすことを考える。このとき, 引き剥がすのに必要な力を Fig. 1 に示すようにベクトルの矢印で表示して, その先端を結 んだ図形が Z 軸に対して非対称になることを,「非対称性」と 呼ぶことにする。一般にはX 軸は吸着面上に任意の方向に採り うるが, 本論文では一意の X 軸方向に対してのみ非対称性を実 現する柔軟スキンについて扱うので, 二次元の問題に限定して 考える.

ロボットの脚の足裏に適用した場合について, 例えば Fig. 1 でロボットが垂直壁を X 軸方向に登る状況として考えると, 接 地相から遊脚相に移行する際に, X 軸の負方向に引っ張ると容 易に剥がれ，接地相において体を持ち上げるためにX 軸の正方 向には引つ張ると剥がれにくい, という Fig. 1 に一例を示すよ うな吸着特性を持つことが望まれる。

2 章では, 対称吸盤および非対称吸盤の形状を提案する。こ れらの吸盤を, 非線形 FEM による構造解析を行って設計した。 また, 機能確認のため, ミリメータースケールのモデルを試作 して実験を行った． 3 章では, 筆者らがこれまでに関係したゴ ム製ソフトメカニズムによる機能性表面修飾の技術 [15]～[19] を参考にした微細ゴム成型技術を用いて，各吸盤をマイクロス ケールで微細化し，ゴム表面上に集積した $[20] .4$ 章では，マ イクロ吸盤を集積した柔軟スキンについて, 段差に対する適応 性と吸着力の非対称性の二つの観点で評価実験を行った.

\section{2. 吸盤単体の設計と基礎実験}

\section{1 吸盤の動作原理}

本論文では，二つのタイプの吸盤構造について検討し，それ ぞれ対称吸盤と非対称吸盤と名づけた，対称吸盤は従来の吸盤 構造と基本的に同じであるが, 非対称吸盤は, 本研究において, 筆者らが新しく考案したものである.

対称吸盤は, Fig. 2 に示すように一定曲率 $R$ をもつ構造を 採用した。非対称吸盤では, 吸着力特性に非対称性を与えるた めに, Fig. 3 に示すように, 吸盤の内部空間の一部をゴムで埋 める構造とした。この部分を内部バンクと呼ぶことにする。目 標とする吸盤の非対称性は, Fig. 3 において, 引き離し方向が $\mathrm{X}$ 軸の正方向の場合に吸着力が大きく, 負方向には吸着力が小 さい特性である。また, 両吸盤は, ゴム弾性体であり, 吸盤と 一体に成型される円柱状の接続柱によって支持される.

吸盤は， 1 章でも述べたとおり，吸盤自体の変形復元に伴う 吸盤内体積変化によって吸盤内圧と外側の大気圧に差が発生す ることで吸着する。その吸着状態までの過程は以下にまとめら れる。

（1）吸盤に押し付け荷重が与えられる.

(2) 吸盤の変形に伴い, 内部の空気が流出する。このとき, 吸 盤内体積を $V_{0}$ とし, 内圧は大気圧 $p_{0}$ と等しいとする.

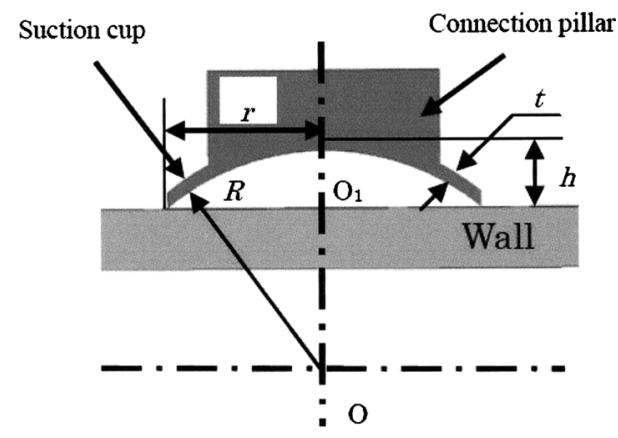

Fig. 2 Design and shape parameters of symmetric suction cup

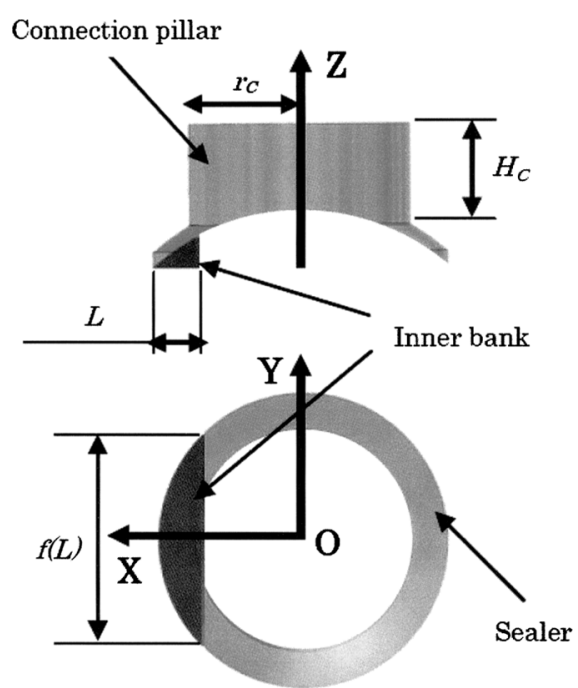

Fig. 3 Design and shape parameters of asymmetric suction cup

（3）荷重が取り除かれる.

（4）ゴムの弾性力により，吸盤形状が復元し，負圧が発生する. また, 吸盤内外の空気圧と吸盤の弾性力がバランスしてい る状態での吸盤内の体積を $V$ とする.

（5）発生した負圧による力 $F$, 弾性力, 摩擦力がつり合い, 吸 着状態となる。摩擦力は無視する。 このとき, 吸盤内が完 全密封され空気の流入がないとする. また, 密封された壁 面との接触面積 $A$ は一定とする.

以上から, 吸盤の吸着力 $F$ は式 $(1)$ のように, 容易に導出 される。（例えば, 文献 [21]）

$$
F=\left(1-\frac{V_{0}}{V}\right) \cdot p_{0} \cdot A
$$

\section{2 非対称吸盤の動作原理}

今回提案する非対称吸盤は, Fig. 3 に示したように吸盤内部 の一部をゴムで埋めた構造（内部バンク）を持っている. 吸盤 に力を加えて吸着面に押しつけていくと，Fig. 4 に示すように, 内部バンクが吸盤外側にめくりあがる現象が生じる。この現象 を利用して，非対称性吸着特性を実現する。

Fig. 4(b) に示すように, 非対称吸盤が吸着した状態では, 吸 盤を押しつける大気圧は吸盤の中心軸に対して図の右側（内部 バンクとは反対側）に偏って分布する. 


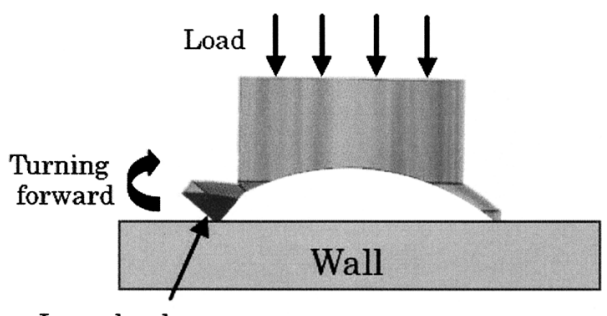

Inner bank

(a) Turning forward of inner bank by load

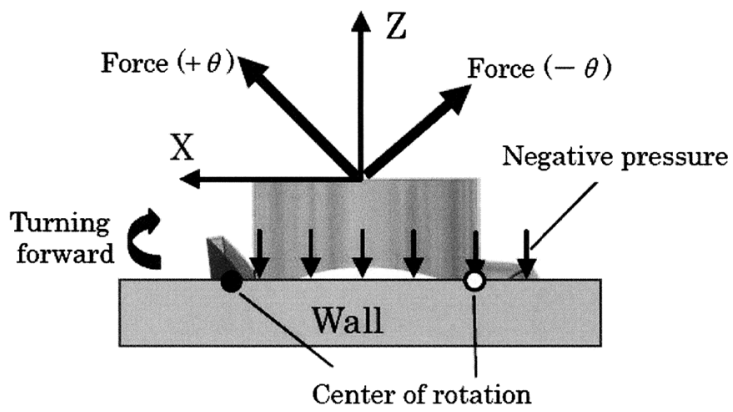

(b) Asymmetric negative pressure distribution and moment

Fig. 4 Adhesive principle of newly proposed asymmetric suction cup

一方，吸盤を引き剥がす外力が接続柱上部に働くと，吸盤の 吸着面にモーメントを発生させる。この外力の X 軸方向の力成 分が正の場合, Fig. 4 (b) に执いて内部バンクの下に存在する

の部分を回転中心として反時計回りのモーメントが作用する可 能性が高い負の場合は Fig. 4 (b) に押いて接続柱の端となる $\bigcirc$ の部分を回転中心として時計回りのモーメントとして作用する と考えられる，上記のように大気圧の偏りがあるため，吸盤は， 時計回りよりも反時計回りに対して，より大きなモーメントに 耐えることができる，このため，X 軸の正方向に引き剥がすほ うが, 負方向に引き剥がすよりも大きな外力が必要となり, 非 対称性の吸着特性が実現される。

\section{3 非線形有限要素法による構造解析}

吸着対象の表面粗さや吸盤の不適切な復元変形による空気漏 れを最小限にし, 安定的な密封性能を実現するために, 本研究 では, 荷重で押し付けられた際の変形および発生する吸盤部の 接触圧力分布に着目した，この分布は，有限要素法によって求 めて検討した。

有限要素法解析では非線形性として, 材料非線形性, 幾何学 非線形性, 境界非線形性の三つを考慮した。解析には, MSC Software 社製 Marc を使用した.

まず, 機能性シートは, 転写性㧍よびシール性に優れたシ リコーンゴム（信越シリコーン社製 KE-1603（A/B）；粘度 A:85/B:50 [Pas] 拈よび硬度 28）を用いた。この応力-歪特性 は，Fig. 5 に示すように，非線形特性である。実測值は，JIS K 6251 加硫ゴムの引張試験方法に準拠して測定している. この 特性を Mooney-Rivlin エネルギー関数の三次近似し解析を行っ た。この近似值と実測值とは, 歪範囲 $0 \%$ 700\%で高い一致を 示すことが確認できる（Fig. 5)。 また，吸盤部の形状は球喨で あり, 押し付けによって大変形が生じるので, 幾何学的非線形

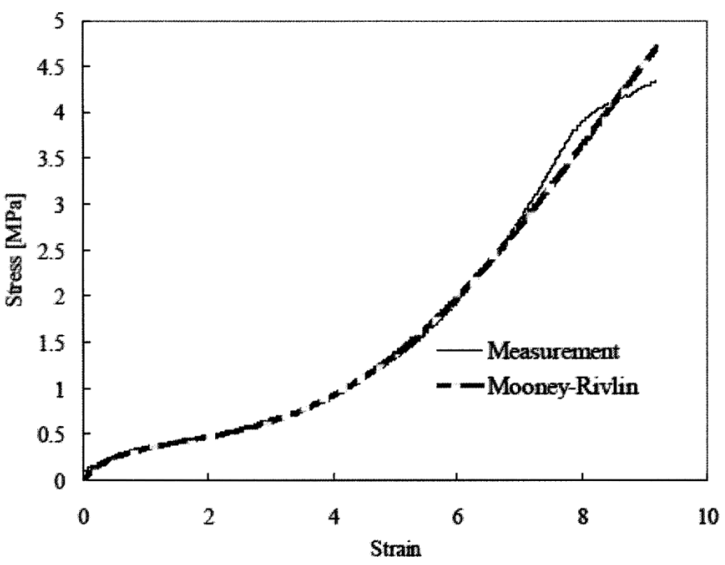

Fig. 5 Experimental results and Mooney-Rivlin model of the rubber material
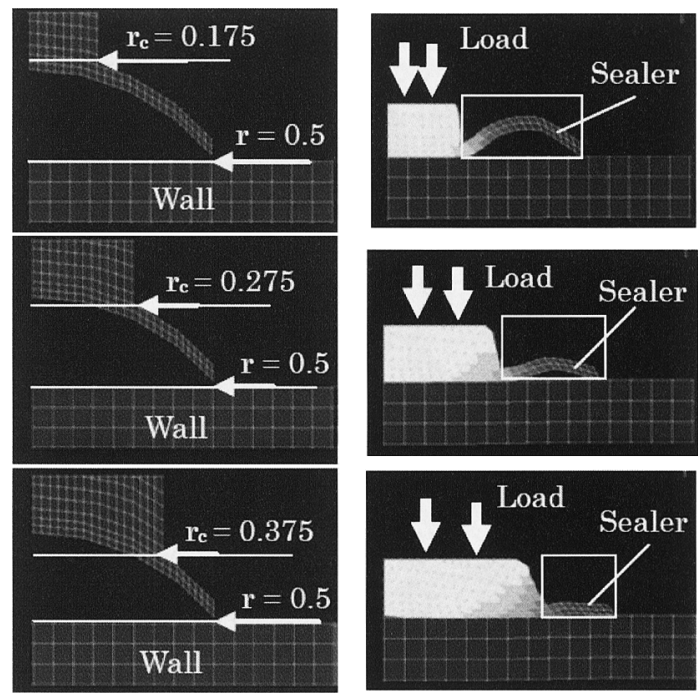

Fig. 6 The results of the nonlinear FEM simulation for various diameters of connection pillars

性を解析に反映した。この吸盤部は被着材表面に接触するため, 摩擦すべりなどの境界の非線形性も考慮する必要がある。境界 条件で摩擦係数を 0.5 と設定し, 被着材表面を平らな面として 解析を行った.

\section{4 接続部と内部バンクの設計パラメータ}

Fig. 2 に示した吸盤構の寸法パラメータのうち, $r, R, h, t$, $H_{C}$ を固定し, 特性への影響が大きいと思われる接続柱の半径 $r_{c}$ および, 内部バンクの大きさ $L$ の最適化を行った，解析は吸 盤直径 $2 r$ で無次元化して行った

特に接続柱は，吸盤部に荷重を印加する働きを担うため，密 封性能を大きく左右する。そそこで，まず，接続柱の直径 $2 r_{c}$ の 最適化を行った. Fig. 6 に示すように, 半径 $r=0.5$ の吸盤部 に接続する接続柱の半径 $r_{c}$ を 0.1 ピッチで増加させ, 押しつけ た際の吸盤変形を調べた，接続柱の半径の増加に伴い，吸盤部 における密封を行う部分の変形が変化することを確認した。そ の結果, 半径 $r_{c}=0.375$ において, 高い接触状態を実現できる ことを確認した。 また，その接触した吸盤部の内部応力分布が， 

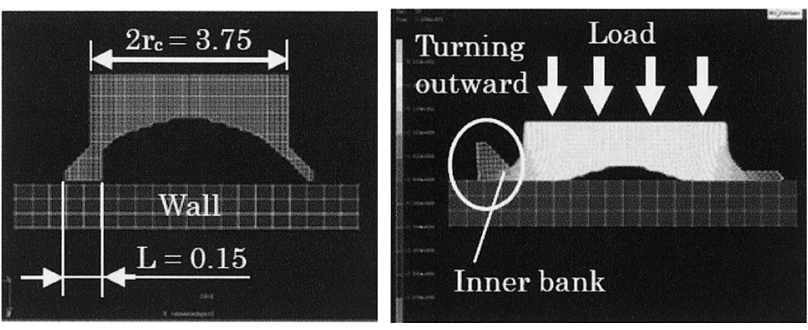

Fig. 7 The result of the nonlinear FEM simulation for the design of inner structure

Table 1 Design parameter of miniaturization and integration

\begin{tabular}{lll}
\hline Symbol & Parameter & Value \\
\hline$r$ & Radius of suction cup (Fig.2) & $250 \mu \mathrm{m}$ \\
$h$ & Height of suction cup (Fig.2) & $113 \mu \mathrm{m}$ \\
$t$ & Thickness of suction cup (Fig.2) & $25 \mu \mathrm{m}$ \\
$R$ & Curvature radius of suction cup (Fig.2) & $390 \mu \mathrm{m}$ \\
$r C$ & Radius of connection structure (Fig.3) & $190 \mu \mathrm{m}$ \\
$H_{C}$ & Height of connection structure (Fig.3) & $115 \mu \mathrm{m}$ \\
$L$ & Length of inner structure (Fig.3) & $75 \mu \mathrm{m}$ \\
$f(L)$ & Width of inner structure (Fig.3) & $175 \mu \mathrm{m}$ \\
$P$ & Pitch between suction cups (Fig. 10) & $800 \mu \mathrm{m}$ \\
$H$ & Height of rubber sheet (Fig.10) & $1000 \mu \mathrm{m}$ \\
\hline \hline
\end{tabular}

外へ向かう方向に単調に減少していることから, 荷重印加時に は, 空気を排出しやすく, また荷重解放時には, この傾向が反 転して適切に密閉作用を示すと予測できる。

次に，この最適化設計された対称吸盤に対して，付加される 内部バンクの設計パラメータ $L$ を決定した。 この非対称吸盤の 場合は，内部バンクが，めくれることを評価条件とした．

Fig. 7 に示すように, 最適な $L$ の場合, 内部バンクは, 荷重 によってめくれる，Lの值が大き過ぎる場合は，この現象は起こ らず, シールが困難なため, 負圧の発生は実現できない. 逆に, $L$ が小さすぎる場合は, 対称吸盤とほぼ同じ挙動を示し, 非対 称性の特性が期待できない，したがって，Lは，めく現象が 現れる最大值として, $L=0.15$ と決定した. Table 1 に, 決 定したマイクロ吸盤のサイズを示す.

\section{5 基礎特性実験}

非対称吸盤の吸着力非対称性を検証する目的で, 直径 10 [mm] の通常サイズの試作吸盤（対称吸盤と非対称吸盤）を製作し，引 き離し試験を行った。

Fig. 8 に，製作した試作吸盤を示す. Fig. 8 (a) は対称吸盤 を, Fig. 5 (b) は非対称吸盤を, Fig. 8 (c) は非対称吸盤の吸着 状態を示している.

この非対称吸盤の内部バンクが Fig. 7 の解析結果と同様に, めくれることを確認した，各吸盤は，アクリル製の平らな面に 押しつけられ，荷重が与えられ解放することで吸着する。そし て, 各吸盤の引き離し実験では, Fig. 8 (c) に示すように, 引き 離し角度を変化させた。

Fig. 9 は, 対称吸盤と非対称吸盤について吸着力と引き離し 角度との関係を調べた実験結果である.10 回の計測で算出した 吸着力の平均值（Fig. 9 で示す・）を結び, 標準偏差をプロット

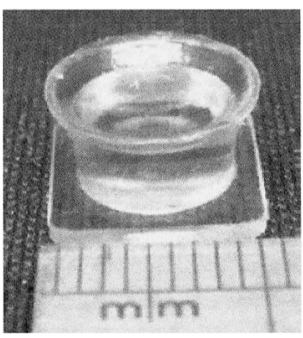

(a) Symmetric cup

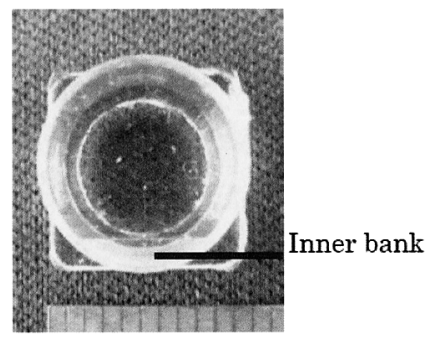

(b) Asymmetric cup

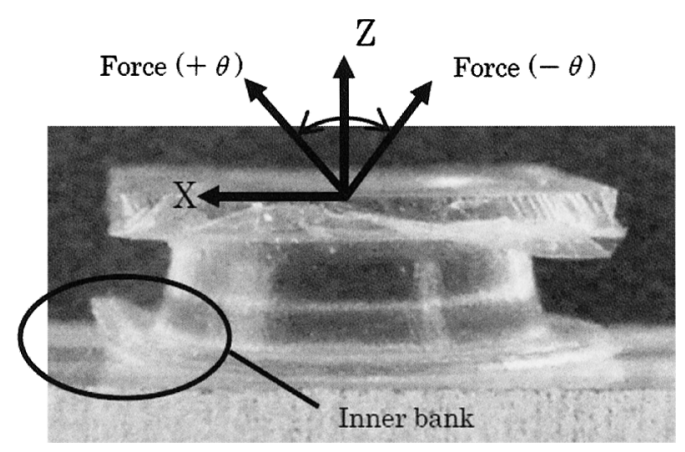

(c) Adhesive sate of Asymmetric suction cup

Fig. 8 Fabricated large size suction cups

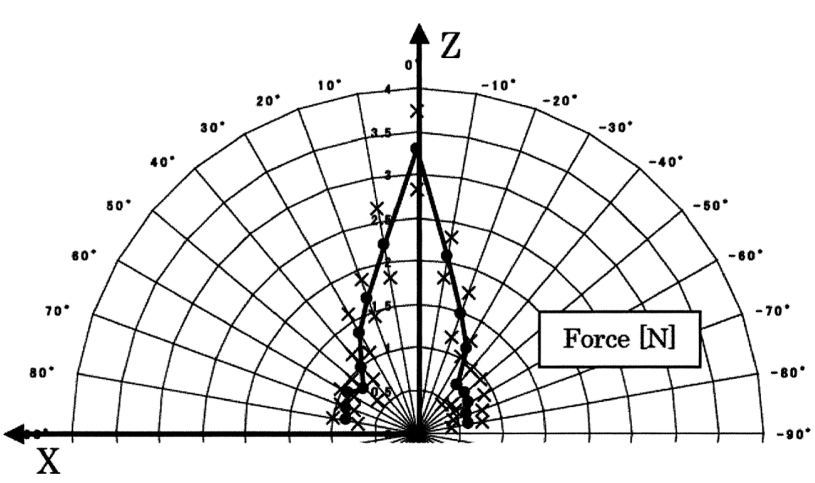

(a) Symmetric suction cup

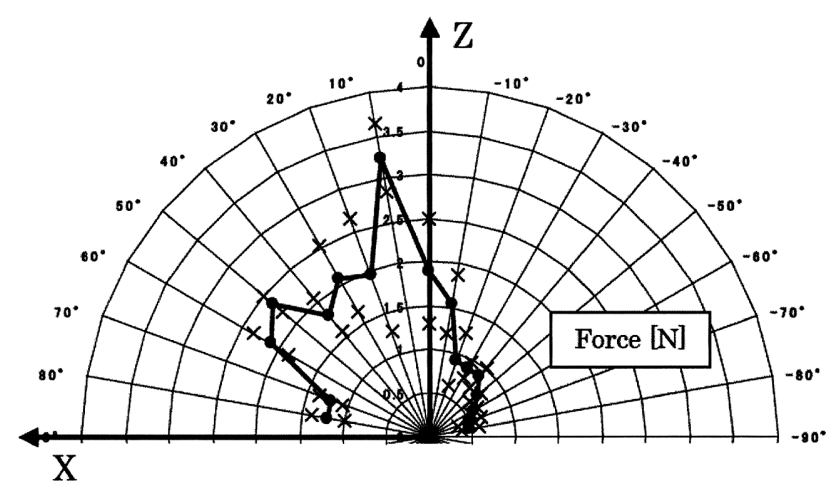

(b) Asymmetric suction cup

Fig. 9 Relationship between adhesion force and pulling angle

して表示している (Fig.9 で示す x). グラフから, 対称吸盤の 吸着力（Fig. 9 (a)）は，対称性を示していることが分かる。一 方, 非対称吸盤は, 正の方向と負の方向によって, 吸着力特性 が異なることが確認できる（Fig.9(b)）. 


\section{3. マイクロ吸盤集積による柔軟スキンの試作}

\section{1 スキンの設計}

2 章の吸盤設計を基に設計した柔軟スキンを Fig. 10 に示す. 集積化のパラメータとして，吸盤間のピッチ $P$ や，基盤となる 柔軟スキンの厚み $H$ を示している。ここで，対称吸盤を有する 柔軟スキンをモデル A，非対称吸盤を有する柔軟スキンをモデ ル B とする.

二つのモデルの各部の大きさは，Table 1のとおりである。各 設計パラメー夕は, Fig. 2, Fig. 3, Fig.10に示すと㧍りである. これらの大きさは, 非線形 FEM の構造解析と精密機械加工の 精度から決定した。

\section{2 剥離膜を利用した微細ゴム成型技術}

試作は Fig. 11 に示すように，上段，中段，下段の三つの精 密金型を用いて，マイクロ吸盤，内部バンク，接続柱，スキン ベースを一体で成型した，この際，成型ゴムを損傷なく安定的 に, 金型から引き離すことが, 重要な問題である。特に微細ゴ ム構造は, 引き離しの際に, 容易に損傷してしまう。

この問題を解決するために，上段型と中段型について，はめ 合わせ面に離型膜を形成した。この膜は, フッ化炭素系化学吸 着膜であり，数ナノレベルの均一な厚みであるため, 金型側の

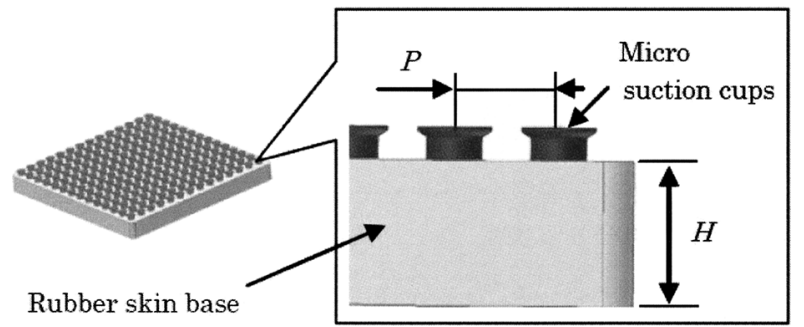

Fig. 10 Design of integrated micro suction cups on the rubber skin base
形状をゴムに損なうことなく転写できる $[22]$.

Fig. 11 に示すように, 微細ゴム成型手法のプロセスは, 次の とおりである。

（1）上段型と中段型について，はめ合わせ面に離型膜を形成す る. (Fig. 11 左上)

（2）液状態のシリコーンゴムを下段型に流し込み，真空脱泡を 行う。 (Fig. 11 左下)

（3）この下段型に対して，中段型と上段型をはめ合わせる. (Fig. 11 中)

（4）シリコーンゴム重合後, 上段型と中段型を, 下段型から分 離する。（Fig. 11 右上）

（5）下段型から離型することで，吸着性柔軟ロボットスキンは 完成する.（Fig. 11 右下）

\section{3 バリ取り機能を有する中段型の形状}

微細ゴム成型では, 型同士の隙間に生じるバリ発生が大きな 問題となる. 今回の試作では, 吸盤の吸着部先端にバリが発生 する. そこで，上段型との，はめ合わせ部分について，中段型 の形状を工夫している。離型の際に, 発生したバリの特定の部 分に応力集中を生じさせることで，その点できれいにバリを切 断することができる。

Fig. 12 は，吸盤形状が形成される部分の拡大図である. Fig. 12 に示す Xの位置に応力集中部を設けることにより, マ イクロ吸盤を設計どおりに切断することに成功した．

\section{4 マイクロ吸盤のゴム成型状態}

Fig. 13 に, 2 種類の柔軟スキンの光学顕微鏡画像と, マイク 口吸盤の SEM 画像を示す. Fig. 13 (a) は対称吸盤で構成された 柔軟スキン A であり, Fig. 13(b) は非対称吸盤で構成された柔 軟スキン B である。両スキンのサイズは, $10[\mathrm{~mm}] \times 10[\mathrm{~mm}]$ である.

Fig. 13 の光学顕微鏡から確認できるように, 両スキンで集積 された全マイクロ吸盤は，設計ど㧍り等間隔に形成されている.

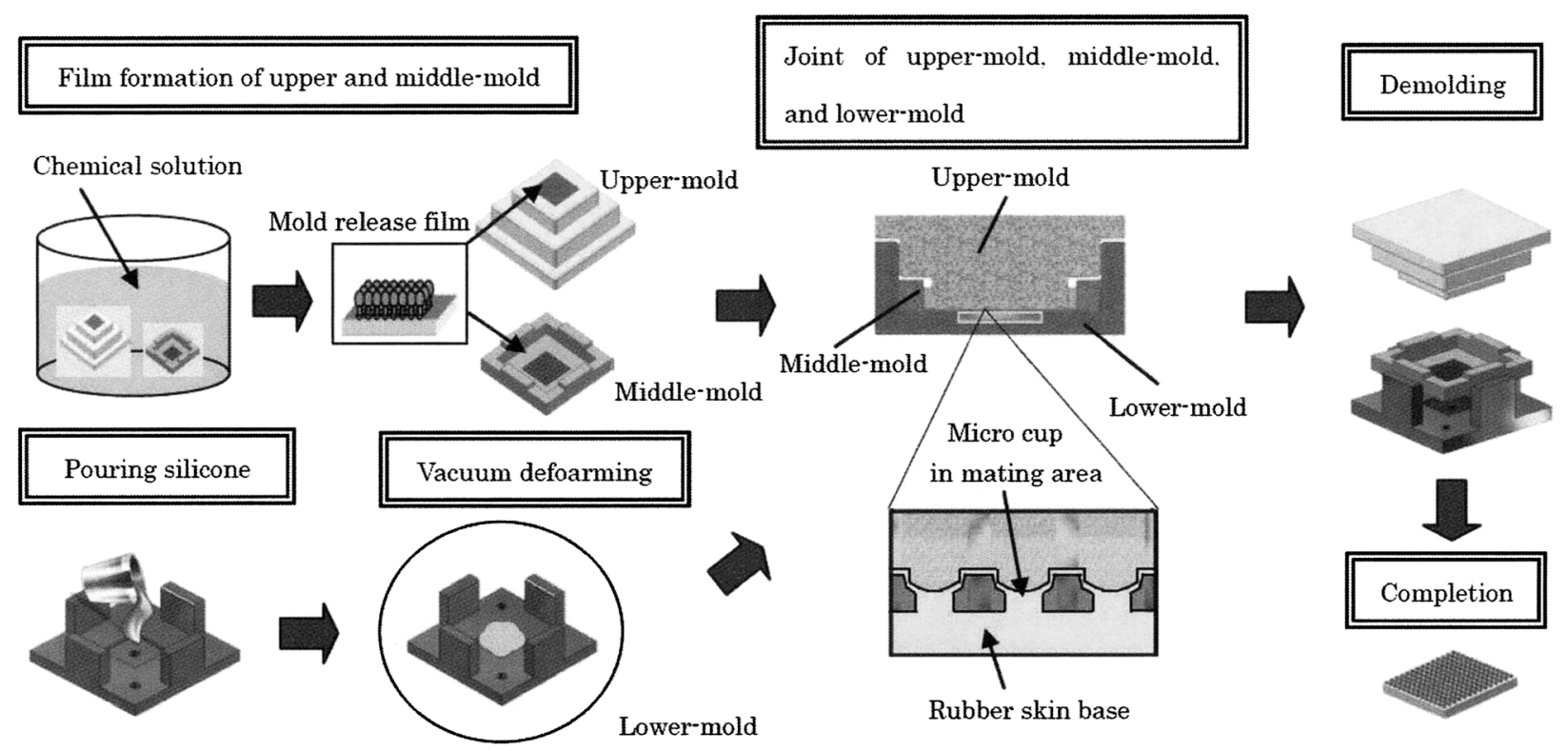

Fig. 11 Fabrication process of adhesion robot skin 


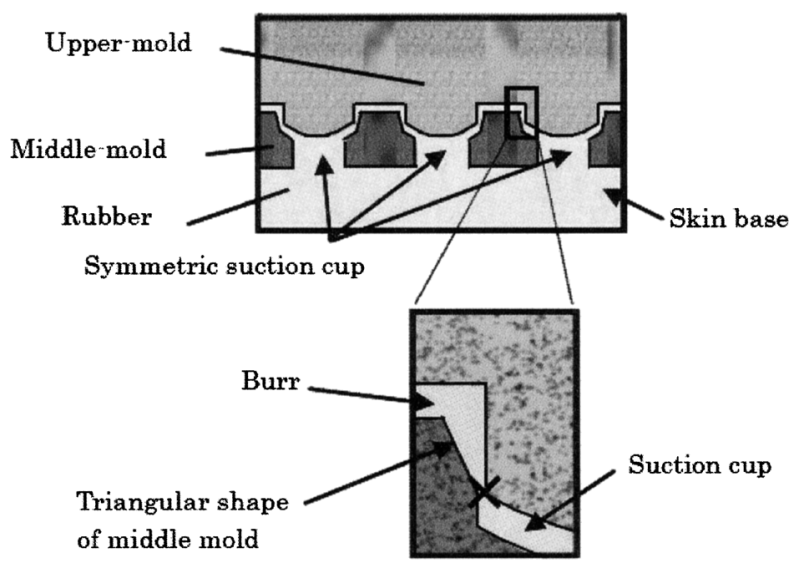

(a) Symmetric suction cups

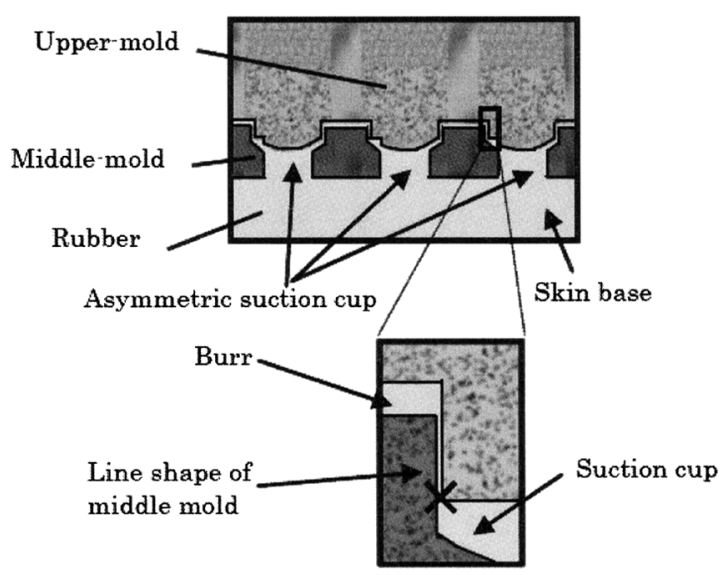

(b) Asymmetric suction cups

Fig. 12 Mold shape around mating area for cutting off burr

また，SEM 画像から，各マイクロ吸盤は，バリがない状態であ り, Fig. 2 と Fig. 3, Table 1 に示すような内部バンクを有する 球喨形状をなすことを確認した. Fig. 14 は，マイクロ非対称 吸盤の表面粗さ曲線である。計測システムは, Nikon 製非接触 三次元表面形状計測システム BW-D50X を用いた. Fig. 14 (a), Fig. 14 (b) は, それぞれ，マクロ吸盤直径 $2 r$, 内部バンクの奥 行き $L$ を測定したデータである， $2 r$ は誤差 $10 \%$ 程度， $L$ は誤 差 $5 \%$ 程度であることを確認した。

\section{4. 評 価 実 験}

\section{1 マイクロ吸盤の観察}

吸着性柔軟ロボットスキンの性能を定性的に検証する目的で 基礎実験として, 光学顕微鏡でゴム表面の吸着状態を観察した。 各実験は，表面に水をたらし，薄くぬれた高湿状態で行った [13].

Fig. 15 に示すように, 柔軟スキン A は，平滑な面だけでな く，曲面に対しても吸着することを確認した，各マイクロ吸盤 が個別に働くことで, 全体として高い形状適応性をもって吸着 できることが明らかとなった。

Fig. 16 では, 柔軟スキン B を平滑な面に吸着させた際のマ イクロ内部バンクの拡大画像を示す．各マイクロ非刘称吸盤の 内部バンクが, Fig. 7 の非線形 FEM 構造解析や Fig. 8 (c) の通
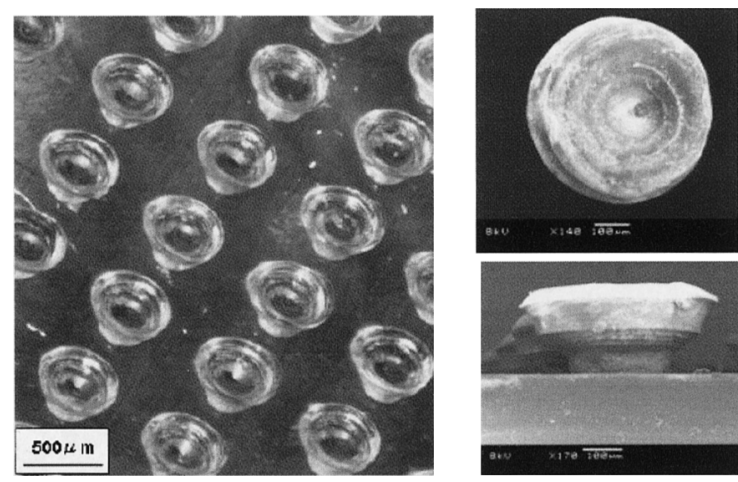

(a) Skin A with symmetric suction cups
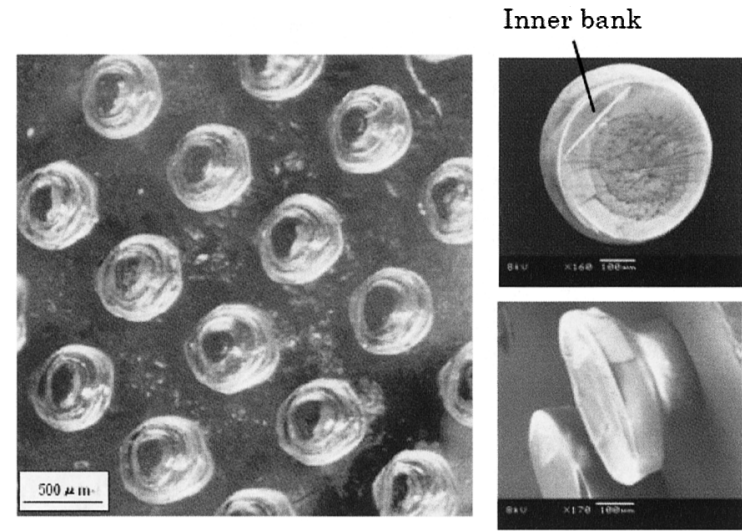

(b) Skin B with asymmetric suction cups

Fig. 13 Photographs of the two types of soft robot skins; optical microscope photographs (left) and SEM images (right)

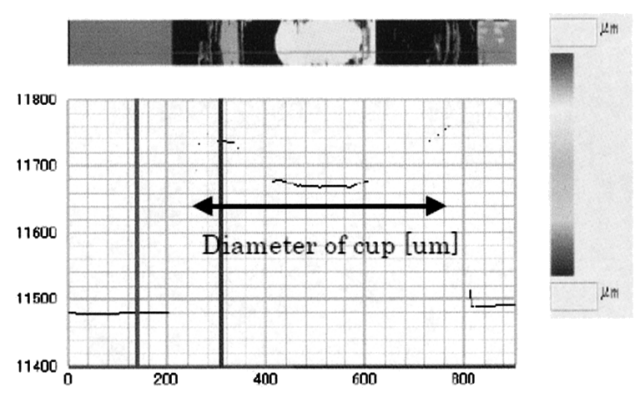

(a) Diameter of cup

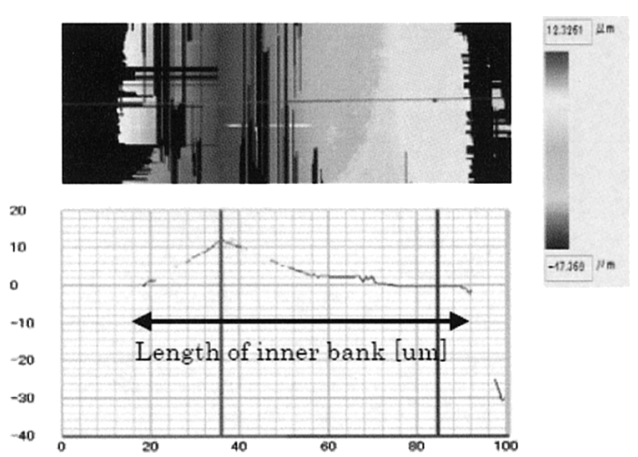

(b) Length of inner bank

Fig. 14 Evaluation of fabricated micro structure by 3D surface measuring instrument 


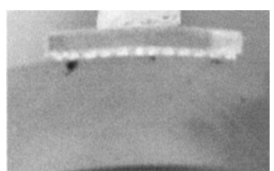

(a) Curvature $80[\mathrm{~mm}]$

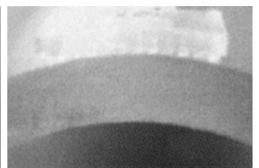

(b) Curvature $40[\mathrm{~mm}]$

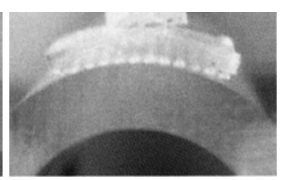

(c) Curvature $20[\mathrm{~mm}]$

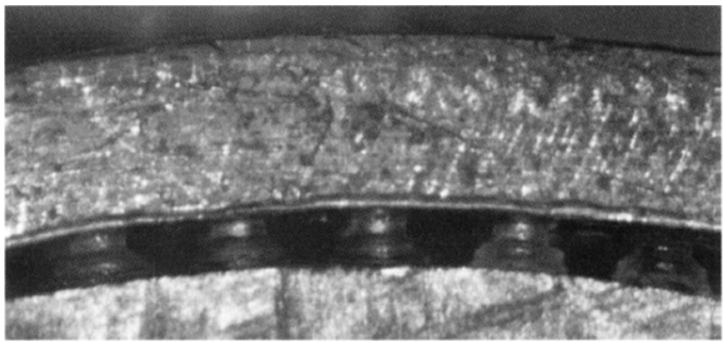

(d) Close-up picture of micro suction cups in case (c)

Fig. 15 Observation of adhesion to flat and curved surface

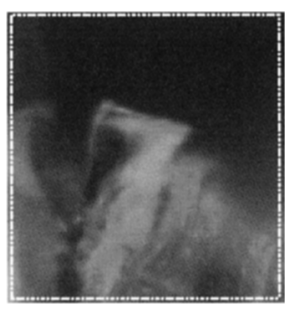

(a) Inner bank

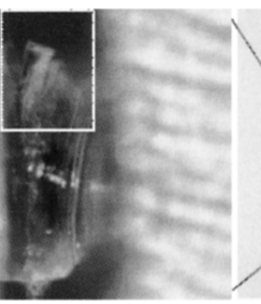

(b) Suction cup

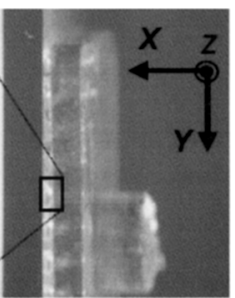

(c) Skin B
Fig. 16 Observation of adhesion of skin B

常サイズの試作吸盤の観察と同様に，めくれることを確認した 通常サイズの試作吸盤の基礎実験から，内部バンクがめくれた 吸着状態では，その吸着力特性に非対称性が生まれることが期 待できる。

\section{2 吸着特性}

柔軟スキン A と柔軟スキン B の吸着特性を実験で計測した。 Fig. 17 に, 実験装置の構成を示す。引張試験機は, 両シート を糸で接続しフォースゲージを介して，0.05 [mm/s] の速度で, 引き離す。この基礎的な実験装置を用いて, 段差面への形状適 応性と吸着力の非対称性について，各実験を行った。

段差面への吸着適応性実験では, Fig. 17 (b) に示すように, 1 枚のガラス板が非可動式ステージに固定されており，もう 1 枚 のガラス板は, 垂直可動式ステージに固定されている。この可 動式ステージを調整することで，段差の高さを任意に設定する ことが可能である，段差に対して，吸着させる柔軟スキンの向 きは, Fig. 1, Fig. 3 で定義した座標系の X 軸と平行な状態と する.

吸着力の非対称性実験では，ガラス板を 1 枚だけ，Fig. 17 (c) に示すような回転ステージに固定した。このステージによって, 引き離し角度を任意に調整することが可能である

各実験において，ゴム表面をウェットな高湿状態とした。この とき各柔軟スキンの吸着力は, 10 回の計測を行い, その各計測 での剥離が発生する瞬間の力を測定し, 平均值として算出した.

Fig. 18 に，段差の高さと吸着力との関係を示す。このとき，

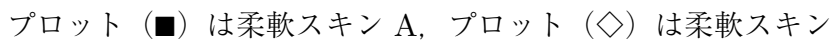

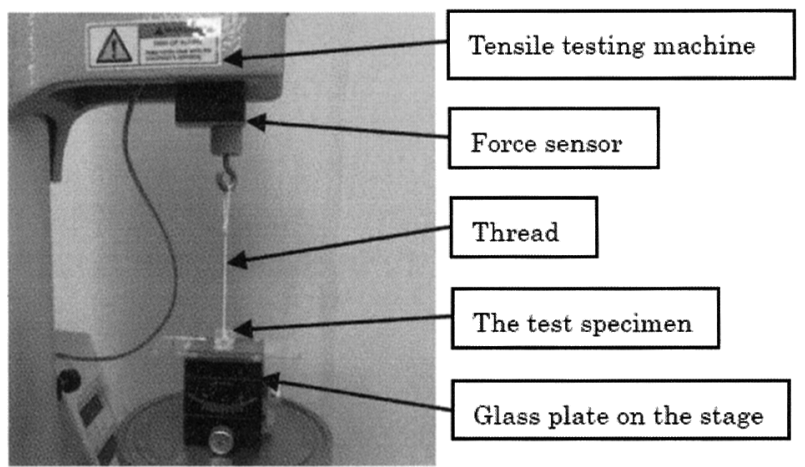

(a) Basic setup

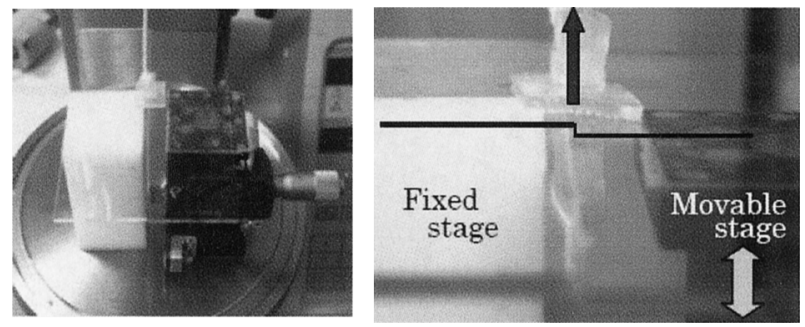

(b) Stages for setting arbitrary bump

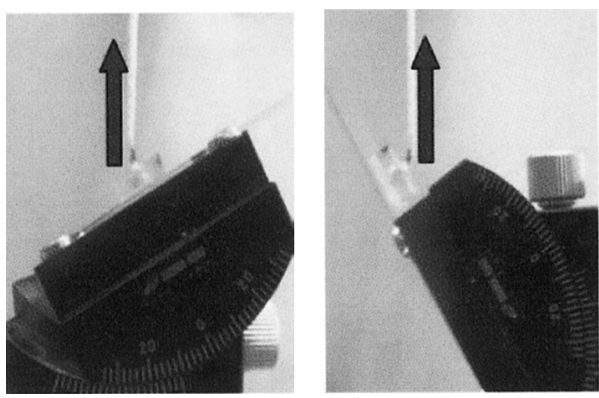

(c) Stage for changing pulling angle

Fig. 17 Experimental setup for measuring adhesion force

B のそれぞれ吸着力の平均值を示している。また，標準偏差を 誤差バーで表示している。柔軟スキン A の場合, 吸着力のばら つきが大きく不安定な吸着といえる。また，段差高さの増加に 伴い，減少しやすいことを確認した。これに対して，柔軟スキ ン Bでは, 段差高さが増加したとしても, 一定の吸着力を安定 的に維持できることを確認した。

Fig. 19 では，平らな面について引き離し角度と吸着力の関係 を示す.このとき, 吸着力の平均值（Fig. 19 に示すの）を線で 結び，標準偏差をプロットで表示している（Fig. 19 に示す×）. Fig. 19 (a) および (b) は，それぞれ柔軟スキン A および柔軟ス キン B の吸着力特性を示している. 直径 $10[\mathrm{~mm}]$ の試作対称吸 盤の吸着特性（Fig. 9 (a)）と同様に，柔軟スキン A は，ほぼ対 称の特性を示した。 これに対して, 柔軟スキン B は, X 軸負方 向において $40^{\circ}$ に極めて小さい吸着力となる非対称性を示して いることが確認できる. Fig. 9 (b) に示した吸盤単体の特性とは 異なる形になっているのは, 集積した吸盤の場合, 個々の吸盤 には, 必ずしもべースにかけた力ベクトルと同じ方向に力がか かるとは限らないためである。 


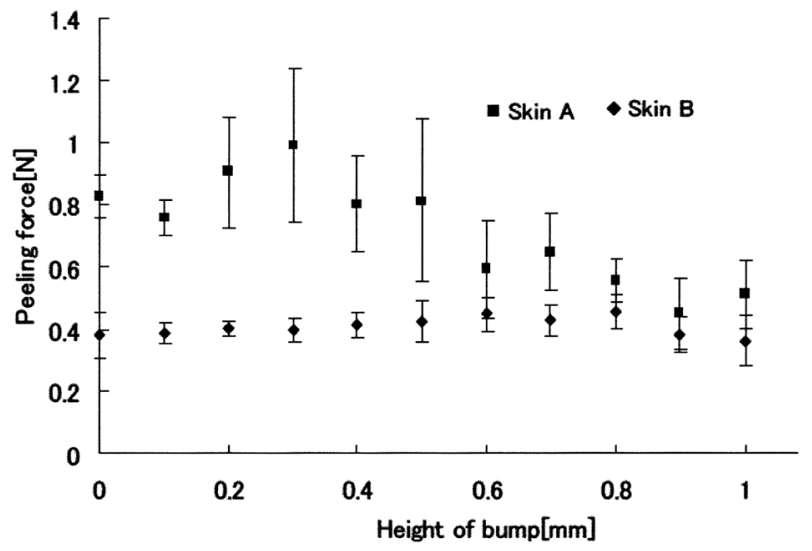

Fig. 18 Relationship between the height of bump and adhesion force

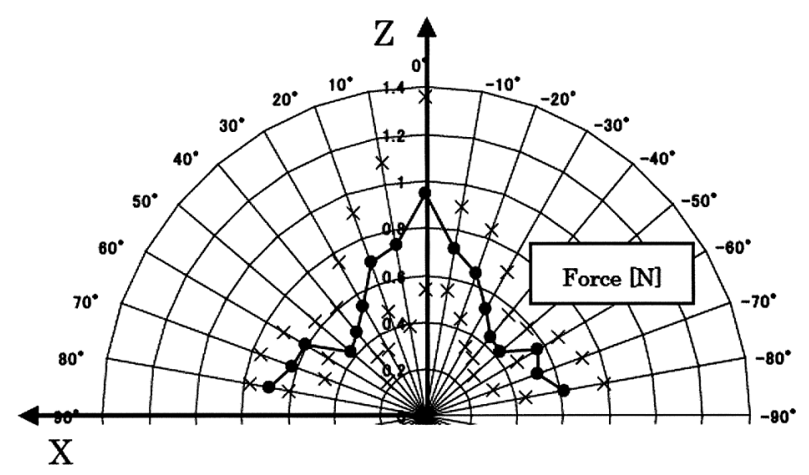

(a) Skin A with symmetric suction cups

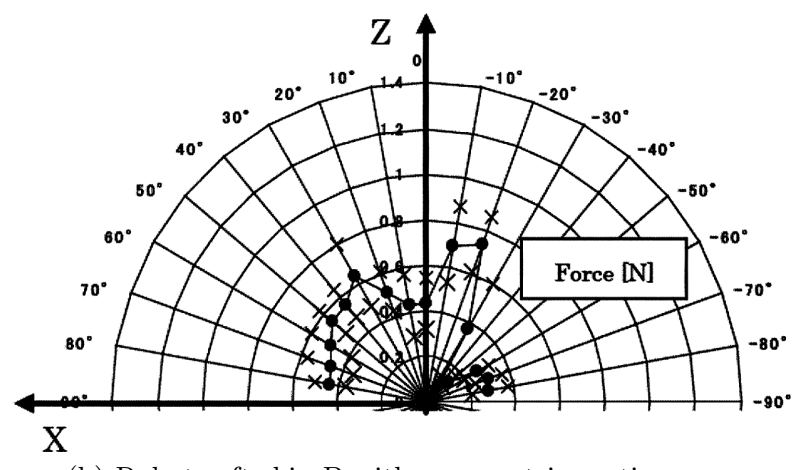

(b) Robot soft skin B with asymmetric suction cups

Fig. 19 Relationship between angle and adhesion force

\section{5. 結言}

本論文では，マイクロ吸盤をゴム表面に集積形成することで, 被吸着面への形状適応性を実現し, さらに非対称形状の吸盤によ り吸着力特性に非対称性を兼ね備えた吸着表面機能を実現した。

本論文に扔ける結論を以下に示す。

（1）マイクロ吸盤を集積することで，吸着面への形状適応性扔 よび吸着力が引き剥がし方向によって異なる非対称性をも つ柔軟ロボットスキンを提案した。

（2）吸盤内部にバンクを設けることで吸着特性に非対称性を有 する非対称吸盤を考案した

（3）直径 $10[\mathrm{~mm}]$ の試作吸盤を用いた基礎実験によって，内部
バンクのめくれる現象により, 吸着力特性に非対称性が生 まれることを実証した。

（4）微細ゴム成型プロセスで, フッ化炭素系単分子膜の離型材 としての利用および応力集中によるバリ取り構造の付加を 実施することで，奥行きの形状を有する外径 $0.5[\mathrm{~mm}]$ のマ イクロ吸盤の集積に成功した.

（5）集積した場合，対称吸盤に比べて非対称吸盤の方が形状適 応性において，ばらつきの小さい安定的な吸着を示すこと を確認した。

（6）非対称吸盤を集積した柔軟スキンで，吸着力特性に非対称 性を確認した

今回開発した吸着性柔軟ロボットスキンは, 壁登りロボット の足裏への適用が期待できる.

謝 辞 本研究の一部は, JSPS 科学研究費基盤研究 (A)（課 題番号 22246019）“マイクロ構造形成によるソフトメカニズム の機能性表面修飾”を受けて実施している.

\section{参 考 文 献}

[1] S. Kim, A.T. Asbeck, M.R. Cutkosky and W.R. Provancher: "SpinybotII: Climbing Hard Walls with Compliant Microspines," IEEE International Conference on Robotics and Automation, pp.601-606, 2005.

[ 2 ] D. Santos, S. Kim, M. Spenko, A. Parness and M. Cutkosky: "Directional Adhesive Structures for Controlled Climbing on Smooth Vertical Surfaces," IEEE International Conference on Robotics and Automation, pp.1262-1267, 2007.

[3] S. Kim, M. Spenko, S. Trujillo, B.H.V. Mattoli and M.R. Cutkosky: "Whole body adhesion: hierarchical, directional and distributed control of adhesive forces for a climbing robot," Proc. of IEEE International Conference on Robotics and Automation, pp.1268-1273, 2007.

[4] 鶴清, 広瀨茂男：“凹凸吸着面対応型永久磁石ユニットの開発”, 日本 ロボット学会誌, vol.26, no.6, pp.683-690, 2008.

[5] C. Balaguer, A. Gimenez, J.M. Pastor, V.M. Padron and M. Abderrahim: "A climbing autonomous robot for inspection applications in 3D complex environments," 2000 Robotica, vol.18, no.3, pp.287-297, 2000.

[6] Y. Zhang and A. Nishi: "Low-pressure air motor for wallclimbing robot actuation," Mechatronics, vol.13, no.4, pp.377392, 2003.

[ 7 ] 三宅徹, 石原秀則 : “空清掃ロボットWallWalker”, 日本機械学会誌, vol.109, no.1051, pp.46-47, 2006.

[8] T. Miyake, H. Ishihara and M. Yoshimura: "Basic Studies on Wet Adhesion System for Wall Climbing Robots," IEEE International Conference on Intelligent Robots and Systems, pp.1920-1925, 2007.

[ 9 ] J. Liu, K. Tanaka, L.M. Bao and I. Yamaura: "Analytical modelling of suction cups used for window-cleaning robots," Vacuum, vol.80, pp.593-598, 2006.

[10] F. Novotny and M. Hork: "Computer modelling of suction cups used for window cleaning robot and automatic handing of glass sheets," Modern Machinery Science Joural, pp.113-118, 2009.

[11] Y. Yoshida and S. Ma: "Design of Wall-Climbing Robot with Passive Suction Cups," IEEE International Conference on Robotics and Biomimetics, pp.1513-1518, 2010.

[12] W. Brockmann and F. Mosch: "Climbing Without a Vacuum Pump," Climbing and Walking Robots PartVIII, pp.935-942, 2005.

[13] 土谷茂樹, 鈴木清光, 松本昌大, 三木政之： “マイクロ構造における表 面間力に関する理論的検討”, 計測自動制御学会論文集, vol.32, no.5, pp.637-645, 1996. 
[14] 下澤楯夫，針山孝彦：昆虫ミメティックス，株式会社エヌ・ティー． エス, 2008.

[15] K. Suzumori and F. Saito: "Micro Rubber Structure Realizing Multi-Legged Passive Walking," IEEE/RSJ International Conference on Intelligent Robots and Systems, Nice, France, September 22-26, 2008.

[16] F. Saito and K. Suzumori: "Micro Rubber Structure Realizing Multi-Legged Passive Walking-Integration and Miniaturization by Micro Rubber Molding Process-," IEEE/RSJ International Conference on Intelligent Robots and Systems, 2009.

[17] K. Suzumori, M. Mihara and S. Wakimoto: "Beautiful Flexible Microactuator Changing its Structual Color with Variable Pitch Grating," IEEE International Conference on Robotics and Automation, 2011

[18] 眞鍋諒一, 鈴森康一, 脇元修一：“マイクロ吸盤集積ラバーシート
の開発”, 日本機械学会ロボティクス・メカトロニクス講演会 2011 1A2-G05, 2011.

[19] 眞鍋諒一, 鈴森康一, 脇元修一：“マクロ吸盤集積ラバーシートの開 発一第 2 報; 非対称吸盤の微細集積化一”, 第 29 回日本ロボット学 会学術講演会予稿集 DVD-ROM, AC1D1-5, 2011.

[20] R. Manabe, K. Suzumori and S. Wakimoto: "A Fuctional Adhesive Robot Skin with Integrated Micro Rubber Suction Cups," IEEE International Conference on Robotics and Automation, 2012.

[21] 大谷技研 (株): 自動機コム, 真空吸着実験, 吸盤, http://www.jidouki. com/archives/571091.html

[22] 山本洋之, 大久保雄司, 小川一文, 内海邦広 : “フッ化炭素化学吸着膜 の離型剤としての応用に関する実験的研究”, 成形加工, vol.21, no.1, pp.38-43, 2009.

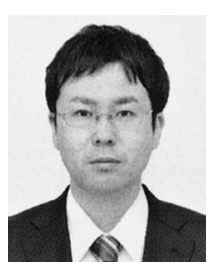

眞鍋諒一（Ryoichi Manabe）

2011 年岡山大学工学部システム工学科卒業. 同年 岡山大学大学院自然科学研究科博士前期課程に入 学, 現在に至る. 主にマイクロゴム構造に関する研 究に従事.

(日本ロボット学会学生会員)

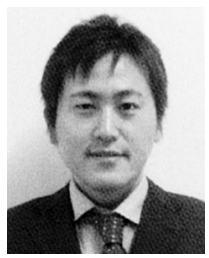

脇元修一（Shuichi Wakimoto）

2007 年岡山大学大学院自然科学研究科博士後期課 程修了．同年岡山大学自然科学研究科助教, 2009 年岡山大学異分野融合先端研究コア助教 (特任), 2011 年より同所属准教授 (特任), 現在に至る.工 学博士. ソフトアクチュエータの開発とその応用に 関する研究に従事。（日本ロボット学会正会員）

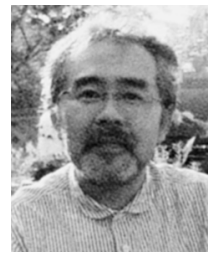

鈴森康一（Koichi Suzumori）

1984 年横浜国立大学大学院工学研究科修士課程修了. 同年株式会社東芝入社. 2001 年まで同社総合研究所 および研究開発センターに勤務。この間, 1990 年横 浜国立大学大学院工学研究科博士課程修了. 1999 2001 年財団法人マイクロマシンセンター勤務. 2001 年岡山大学教授，現在に至る。工学博士。ニューア クチュエータとその応用に関する研究に従事. 1992 年日本ロボット 学会技術賞, 2000 年日本機械学会賞 (論文), 2000 年日本ロボット 学会論文賞受賞. 